\title{
Interesting Bird Records from across the Prairies
}

A GRAY JAY (Perisoreus canadensis) seen at Skull Creek, near Maple Creek, in southwestern Saskatchewan this winter was reported by Steve A. Mann as a "first" for his district. The jay was noted in evergreens south of the house on November 21, 1961, and seen again near the house on November 24 and December 3 (the Sunday before $\mathrm{Mr}$. Mann wrote to us about it). The jay appeared only briefly at the house, and then flew into the bush along the wooded Skull Creek. The Gray Jay (Canada Jay) has not been seen in the area before by Steve Mann who has lived all his life at Skull Creek, and it is not reported in the Cypress Hills by W. Earl Godfrey in his Birds of the Cypress Hills and Flotten Lake Regions, Saskatchewan (1950).

Along the North Saskatchewan River at the Borden bridge, a S T E L L ER' S J A Y (Cyanocitta stelleri) was observed on October 29, 1961, by J. Bernard Gollop. The Steller's Jay was seen in the sun at close range, with $7 \times 50$ binoculars. Interestingly, a Blue Jay was seen on the same day in the same place.

The Steller's Jay is not often recorded in Saskatchewan. It was included in the first provincial bird list, H. Hedley Mitchell's Catalogue of the birds of Saskatchewan (1924), on the strength of a specimen taken at Indian Head on May 24, 1923, by Geo. Lang. In C. Stuart Houston's check-list of The Birds of the Yorkton District, Saskatchewan, two records are given for the Yorkton district; a pair reported by Frank Baines as residing on a farm near Saltcoats one summer in the 1920's, and a close-up view of one at Yorkton seen in the spring of 1944 by Pauline Summers.

GOLDEN-CROWNED KINGLETS (Regulus satrapa) were noted in unusual numbers in fall migration (October 7-14, 1961) at Spirit Lake, north of Yorkton, by William Anaka. Small numbers were scattered throughout the woods everywhere during the week, the first time that Golden-crowned Kinglets have been observed in this area in any numbers. The first record of Goldencrowned Kinglets in the Yorkton district was submitted to the Blue. Jay by William Anaka in 1956 (cf. Blue Jay, 14:119). On October 31 of that year a Golden-crowned Kinglet was identified in his yard, and it was noted then that Houston's list for the area (1950) did not include this species.

Sometimes reords from previous years suddenly come to light that are worth recording. Recently a letter from Donald J. Buckle of Lady Lake, Saskatchewan, recalled seeing a male SCARLET TANAGER (Piranga olivacea) in early June, 1958. Buckle saw the bird when it "perched for several minutes in the upper branches of an aspen singing its 'hoarse Robin' song, flew to another aspen, and then flew off." He identified it by its contrasting red body and black wings and its song. Although there have been a number of other sight records of the Scarlet Tanager in Saskatchewan, no specimen has been taken in the province and the bird is not on the provincial check-list.

An INDIGO BUNTING (Passerina cyanea) was seen several times during late October, 1961, by Mrs. Bill Richards at 116 3rd Street, Saskatoon. Finally it was enticed into a banding trap there on October 30, and banded by Dr. C. Stuart Houston. It looked exactly like the female depicted in Peterson's new Field Guide to the Western Birds. It returned to Richards on November 1 ond was lact seen November 2.

This was the fourth record for Saskatchewan-and the first Indigo Bunting to be banded in the province. Previous Saskatchewan records were: two seen at Indian Head in June, 1890, by George Lang (Mitchell, Can. Field-Nat. 38:115, 1924); a male collected at Estevan May 28, 1893 by D. L. Thorpe and reported by Ernest Thompson Seton (Auk 25: 454, 1908) and a pair seen near Armley on June 23, 1927 by Maurice G. Street (C. Stuart Houston and Maurice G. Street, 1959, Birds of the Saskatchewan River). 
An interesting 1961 Manitoba breeding record of the Indigo Bunting was sent to the Prairie Nest Records Scheme by Gordon Smith of Winnipeg who noted a nest, July 7, 1961, near Grand Beach.

In addition to the Saskatchewan records we have a record of a WANDERING TATLER (Heteroscelus incanum) seen at Jasper, Alberta, by E. Otto Höhn of the University of Alberta. Professor Höhn recorded his observation in this way: "The bird was seen on the rocky shore of Patricia Lake near the town of Jasper in Jasper National Park on July 2, 1961, at a distance of about 10 yards. It was observed through $10 \times 50$ binoculars. I noted the following points about it at the time: size about that of a Greater Yellowlegs, but more compact in build with relatively thicker and shorter legs; bill black or dark grey, legs yellow. The bird often teetered in the manner of a Spotted Sandpiper. In flight the entire upper surface was an even grey, i e., there were no wing bars and no rump markings. The underparts were irregularly marked with dark grey and white, but did not show the regular barring. I've seen adults of this species on the B.C. coast. The call note was 'tee tee tee tee tee'." Professor Höhn refers to this as the third record of the species for Alberta. The only record given for Alberta in the Birds of Alberta by W. Ray Salt and A. L. Wilk (1958) is a specimen collected May 30,1938 , on the east shore of Swan Lake near the Alberta-B.C. boundary west of Grande Prairie. The bird is not on the Saskatchewan checklist.

\section{TOWNSEND'S SOLITAIRE AT FORT QU'APPELLE}

\section{by E. Manley Callin, Fort San}

This item is written partly to report an extremely rare visitor to this area and partly to describe another personal experience in regard to the value of that "second look". Criticism is frequently levelled, and rightly so, at hasty identifications or "snap judgments" because they may result in a common bird being misidentified and reported as a rare species. However, it is well for us to remember that the danger of the "snap judgment" also works in reverse as it may result in a rare species being passed by in haste.

At 1.30 p.m., on Nov. 10, 1961, I stepped outside our house to return to the office and a casual glance revealed a dark robin-sized bird with fairly long tail reaching for berries in a near-by Mountain Ash. Further details were not clear as I was facing a bright sun and in my hurry I was tempted to accept it as a Pine Grosbeak as that species had been seen many times daily in the area. Fortunately the bird turned at this moment and a light-colored patch was seen on the wing instead of the wing bars of the Grosbeak. I immediately approached the bird from another direction and thus identified my first Townsend's Solitaire in almost 36 years of observation. Though it twice flew a short distance, I eventually watched it with binoculars from a distance of about 25 feet as it fed leisurely upon hawthorn berries or merely perched in its noted attitude of quiet solemnity.

As most of the readers know, the normal home of the Solitaire is in the mountains and foothills but it is noted as an erratic wanderer in spring and fall. Though an occasional bird has been seen at Regina almost every year since 1954, it is considered rare at Regina and is much rarer to the north and east. As a matter of fact I have records of about 20 observers for the eastern half of the Qu'Appelle Valley area, some of the records dating back slightly over 100 years, and not one of the observers has listed the Solitaire.

Editor's Note: The Townsend's Solitaire reported at Regina on the Christmas Count, December 24, 1961, was still in the same location in a small park in the north of the city at the time of The Blue Jay going to press (noted January 20). Active and healthy in appearance, the bird seemed prepared to spend the winter in Regina, as one did in 1960-61. (cf. Margaret Belcher's Birds of Regina. 1961. Spec. Publ. No. 3, S.N.H.S.).

\section{BANDED PURPLE FINCH RECOVERED AT YORKTON}

by Larry A. Morgotch, Yorkton

When Carol Beaumont and Charyl Wiley of Yorkton reported finding a banded Purple Finch along a city (Continued on page 39) 